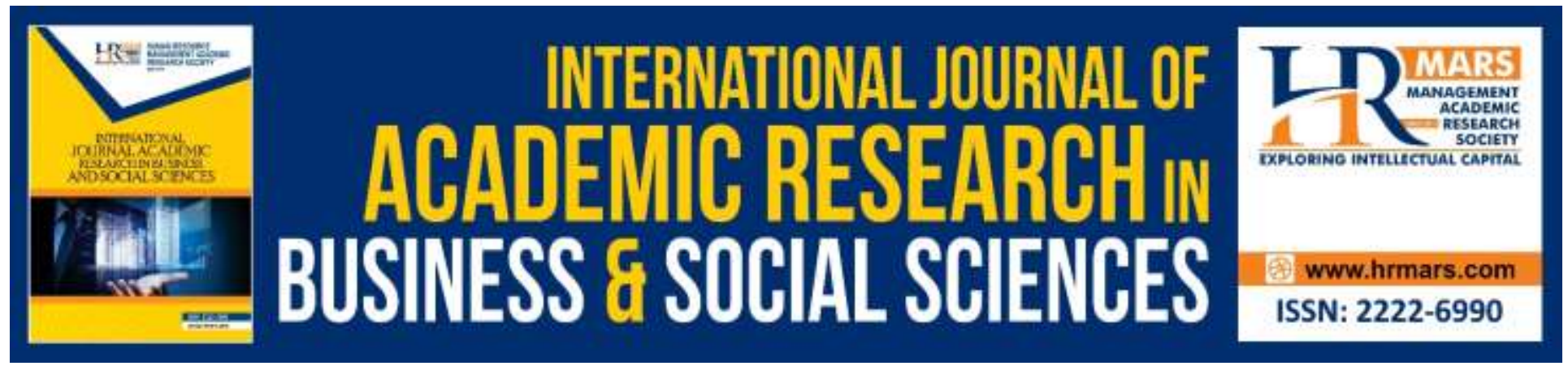

\title{
Hablumminallah among Successful Muslim Women Entrepreneur: An Exploratory Study
}

Syarifah Md Yusof, Abu Bakar Hameed, Raziah Md Tahir \& Azizah Othman

To Link this Article: http://dx.doi.org/10.6007/IJARBSS/v8-i5/4480

DOI:10.6007/IJARBSS/v8-i5/4480

Received: 26 Mar 2018, Revised: 19 April 2018, Accepted: 26 April 2018

Published Online: 16 May 2018

In-Text Citation: (Yusof, Hameed, Tahir, \& Othman, 2018)

To Cite this Article: Yusof, S. M., Hameed, A. B., Tahir, R. M., \& Othman, A. (2018). Hablumminallah among Successful Muslim Women Entrepreneur: An Exploratory Study. International Journal of Academic Research in Business and Social Sciences, 8(5), 1015-1027.

Copyright: (C) 2018 The Author(s)

Published by Human Resource Management Academic Research Society (www.hrmars.com)

This article is published under the Creative Commons Attribution (CC BY 4.0) license. Anyone may reproduce, distribute, translate and create derivative works of this article (for both commercial and non-commercial purposes), subject to full attribution to the original publication and authors. The full terms of this license may be seen

at: http://creativecommons.org/licences/by/4.0/legalcode

\begin{tabular}{|c|c|}
\hline \multicolumn{2}{|c|}{ Vol. 8, No. 5, May 2018, Pg. $1015-1027$} \\
\hline http://hrmars.com/index.php/pages/detail/IJARBSS & JOURNAL HOMEPAGE \\
\hline
\end{tabular}

Full Terms \& Conditions of access and use can be found at http://hrmars.com/index.php/pages/detail/publication-ethics 


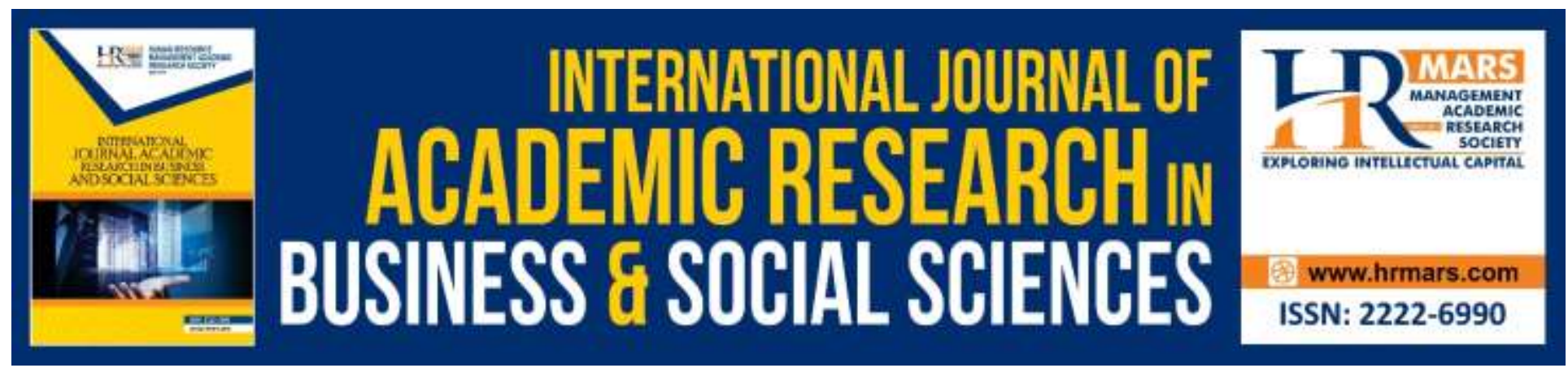

\title{
Hablumminallah among Successful Muslim Women Entrepreneur: An Exploratory Study
}

\author{
Syarifah Md Yusof, Abu Bakar Hameed, Raziah Md Tahir \& \\ Azizah Othman \\ Islamic Business School, Universiti Utara Malaysia Sintok, 06010 Universiti Utara Malaysia, \\ Kedah
}

\begin{abstract}
Islam concerns on both the relationship between man and Allah (hablumminallah) and also between man and man (hablumminannas). Hablumminallah is the individual's relation with Allah. The good relationship With Allah (hablumminnallah) is the main prequisite for Muslim entrepreneurs to achieve success (al-falah). However, unparallel actions and reactions with the teachings of Islam far detour from the effort to create the good relationship with Allah (hablumminallah), furthermore missed the target of achieving al-falah, that is the ultimate success of the world and hereafter to becoming a Muslim entrepreneur. Somehow, the research that's looking into the hablumminallah in the entrepreneur's circle is quite limited. Hence this paper explores the dimensions of hablumminallah among Muslim women entrepreneurs succeeding as the main foundation of the formation of entrepreneurial networks, thus becoming the basis for the success of Muslim entrepreneurs. This research has utilized the qualitative approach. The interview method was used to collect data from successful Muslim women entrepreneur. The interviewees were chosen by using purposive sampling technique. Results from the research shows that Muslim women entrepreneur successfully keep the hablumminallah relationship through faith dimension, worship and morality. The findings of the research will be a guide to entrepreneur especially Muslim women to attained success in business.
\end{abstract}

Keywords: Islamic Entrepreneurship, Women Muslim Entrepreneurship, al-Falah.

\section{Introduction}

Islam concerns on both the relationship between man and Allah (hablumminallah) and also between man and man (hablumminannas). Hablumminallah is the individual's relation with Allah. Hablumminallah provides the basis for capacity to obey and follow the Shariah.

In the context of Islamic entrepreneurship, hablumminallah is one of the dimensions that form a holistic network of Muslim entrepreneur (Hamed \& Yusof, 2008). The holistic network of 
Muslim entrepreneur is a comprehensive entrepreneurial network concept in line with the characteristics of Islamic religion itself. It consists of three dimensions. Hablumminallah is the first dimension. Secondly, hablumminannas is the network of entrepreneurs with humans and the three, networks of entrepreneurs with nature. These three dimensions of the network are built with one purpose, namely to achieve al-falah which is to gain success in the world and in the hereafter. Therefore, to succeed, Muslim entrepreneurs are subject to the concept of relationship with Allah SWT (hablumminallah), human relationships (hablumminannas) and relationships with the environment in each of their actions (Rameli, Aziz, Wahab \& Amin, 2014).

The holistic network of entrepreneurs is based on the tawhid philosophy which is the foundation of the beliefs and the holdings of Islam. Tawhid explains the nature of the existence of God and the nature of human life (entrepreneur) in this world. Humans are created by Allah and are given the responsibility of being the caliph and at the same time as the servants of Allah. As caliph then human beings are entrusted with various resources that need to be dealt with fairly and equitably. As a servant, man cannot escape from the will of His Creator to carry out various activities of worship to Allah s.w.t. This involves the submission of human beings to Allah and the exercise of responsibility based on the faith, shariah and morals. The three fundamentals lead the entrepreneur towards the perfection of humanity to achieve al-falah the pleasure of Allah in the world and in the hereafter.

Good relationship with Allah (hablumminallah) is a major prerequisite for Muslim entrepreneurs to achieve success (al-falah). However, there are Muslim entrepreneurs who ignore their obligations to Allah by abandoning fardhu prayers due to busy business, employing shaman services to underline business, deceiving, and many more. Practicing practices that are not in line with the teachings of Islam far outweigh the effort to establish a good relationship with Allah (hablumminallah), further straying from the goal of al-falah which is the success of the world and the hereafter that is the goal of Muslim entrepreneurs.

However, it is quite difficult to find a study that looks at hablumminallah aspects among entrepreneurs. Hamed and Yusof (2008) discuss the network of holistic entrepreneurs by making hablumminallah as one of the aspects in the network of entrepreneurs. Nevertheless, the writing is a conceptual form. The study of spiritual practice is seen as related to hablumminallah as hablumminallah can be constructed through spiritual practice (Hamed \& Yusof, 2008). The study of spirituality in entrepreneurs found that spiritual dimension is like trust, worship and repentance (Mohsen, 2007; Kamil, Al-Kahtani \& Sulaiman, 2011) tawakal, qanaah, sincere, patience, dhikr (Kedah \& Adamu, 2011). Mubarak, Rahman and Yaacob (2015) and Azmi \& Yaacob (2012) found that spiritual practice contributed to the success of Muslim entrepreneurs.

As a consequence, for the purpose of this paper the concept of hablumminallah will be the central focus of the discussion. This study explores the dimensions of hablumminallah among successful Muslim women entrepreneurs as a key foundation of the formation of entrepreneurial networks, thereby becoming the basis of the success of Muslim entrepreneurs. 


\section{Hablumminallah Concept}

The hablumminallah concept in entrepreneurship refers to a Muslim entrepreneur relationship with God. If seen in the basic clue of the religion of Islam, hablumminallah relations can be built through the dimension of faith or faith, shariah or moral.

Faith from the perspective of the term intends to identify with confidence in the heart, pledge with the tongue and work with limbs (Din, 2015). Faith will give a result of the practice or worship and individual morals. Faith is the basis of human relationships with Allah (hablumminallah). Allah explains this in the Quran through His words which means:

"They only are the (true) believers whose hearts feel fear when Allah is mentioned, and when revelations of Allah are recited unto them they increase their faith, and who trust in their Lord; (2) Who establish worship and spend of that We have bestowed on them. (3) Those are they who are in truth believers. For them are grades (of honour) with their Lord, and pardon, and a bountiful provision. (4)."

(Surah al-Anfal, 8:2-4)

Worship in Islam carries a sense of obedience, submission, worship, prayer or seeking help and protection only to God s.w.t who is the creator, owner and human protector (Din, 2015). Faith in Allah is the basis of worship. All the worship performed must be merely devoted to God. The human function on the face of the earth is to worship God as a sign of gratitude for the gift of mercy to infinite God (Din, 2015). Existence of special worship such as prayer, fasting, alms and zakat solely because obedience and servitude to Allah can maintain good relationship with Allah.

Morality is one aspect of Islamic teachings that also affects one's hablumminallah. Morals refer to behavior, good behavior, morals, morals and habits (Kamus Dewan Online). In terms of terms, al-Ghazali (1990) states that morality is a character that is embedded in the soul of a person, which will spontaneously produce deeds without the need for thought beforehand.

Good morals are the result of worship being implemented. For example al-Qaradawi (1973) states that zakat worship cleanses the soul from the stinginess and greed. Zakat forms a generous character by educating the infidels and helping others. One who has a noble character is the beloved of God, thus showing a good relationship with God. On the other hand, AlQaradawi (2010) emphasized that if the worship performed by a person does not constitute moral character and character, then his worship is of no value to God. The worship that God denies shows the incompetence of a person's relationship with God.

The three elements, namely faith, worship and moral, are very important because it can create a person's relationship with Allah. The proper creed becomes the basis of the charity of worship and produces noble character. The combination of these three elements must be owned by every Muslim to ensure a good relationship with God. With noble character, man will be happy 
INTERNATIONAL JOURNAL OF ACADEMIC RESEARCH IN BUSINESS AND SOCIAL SCIENCES

Vol. 8, No. 5, May 2018, E-ISSN: 2222-6990 ㄷ 2018 HRMARS

in his life world and in the hereafter. Likewise for successful Muslim entrepreneurs, they must have these three elements to achieve al-falah.

\section{Successful Muslim Women Entreprenuer}

Kuratko and Hodgetts (2007) defined entreprenuer as an individual who identify chances whereas others defined them as problems. Muslim entreprenuers are individuals whose bussinesses are producing products or offering services which comply to the Islamic practice so as to gain the halal sustenance (Samsudin \& Kamri, 2008). In summary, a Muslim entrepenuer is a Muslim that involves himself in the business activity, offering products and services while complying with the Islamic practice in the management of their bussiness activity.

The success of a Muslim entrepreneur is pushed by the spiritual practise that is being exercised by them. The characteristic of the spiritual practice influenced the entrepreneur's motivation in running their business until they achieved success in the business involved (Azmi \& Yaacob, 2012; Azmi, 2014; Mubarak, Rahman \& Yaacob, 2015). Among the practices discussed are inclusive of referring to the Islamic sources that is Al-Quran in daily activities, pray five times a day, pay the zakat, giving the poor and needy, praying the extra prayers like tahajud and dhuha.

The successful Muslim entrepreneur also has specialized criteria and characteristics. Abdullah (2013) found five criteria that successful entrepreneurs have and they are holding on tightly to the Islamic way of life, working towards the ways allowed by the religion, appreciating the noble values, giving towards the way of Allah and fulfilling the responsibiliy towards oneslf, family ang workers. The specific criteria are creativity and innovation, the ability to manage, orientated by the future and be motivated. Rameli, Aziz \& Wahab (2013) stated taqwa, prioritising halal, no wastage, practise utmost loyalty to Allah, have high moral standards, have high trust from others, very concerned towards welfares, very knowledgable and taking care of the community and environment as criterias for Muslim entrepreneur. Research also implies that Islamic practise that exist within a Muslim entrepreneur is the important base and asset to be successfull in business.

Briefly, studies on Muslim entrepreneurs found out that successful Muslim entrepreneurs correlated to the appreciation of religious teachings in life and business. Thus, this study explores the concept of hablumminallah in contributing to the good relationship between entrepreneurs with Allah.

\section{Methodology}

This phenomenological form of study is aimed to explore the practice that created hablumminallah in the scope of successful Muslim Women entrepreneur. Qualitative approach is used to achieve the purpose of this study. Data were collected through in-depth interview with successful Muslim women entrepreneurs. The purposive sampling technique is used to choose the sample of the research. The scope of Muslim women entrepreneurs is Muslim women who founded and managed businesses from scratch to thriving. The criteria of successful entrepreneurship from the point of selection of informants are based on business continuity of 
not less than five years. With regard to saturation of data, the entire informant involved is four people.

The next process is the creation of an interview protocol regarding self background and business and the practice that builds hablumminallah in the context of entrepreneurial relationships with its Creator who leads to business success. It encompasses two processes namely the process of questioning and verification of interview questions by experts. Interview questions are based on research questions and literature review. The interview protocol is a research guide in collecting the data needed to answer the research questions. To ensure that researchers obtain the desired data, authentic and reliable, probing techniques are used during interviews. Interview questions are validated by experts in the field of qualitative questions.

Before the interview, the researcher contacted the informant to determine the date of the interview. Interviews are held at the informant business premises. This provides additional information about the situation on their premises. Once the interview is over, the researcher provides an interview transcript according to the dialog during the interview.

General inductive method for qualitatif research proposed by Miles, Huberman and Saldana (2014) is applied in data analysis. This method employs three level of analysis namely Data condensation, Data Display and drawing conclusion and verification.

\section{Finding and Discussion}

Four successful Muslim women entrepreneurs who started their business, owning and managing their own businesses in Kedah were chosen as informants for interviews. All the informants have experience in business for a period between 6 to 16 years in different kind of business. First informant (R1) is in cosmetic business, second (R2) is in frozen food processing, third (R3) is in construction and the last (R4) is in jewellery shop.

Based on in-depth interviews and data analysis, the findings reveal three key themes that make up the habluminallah for successful Muslim women entrepreneurs are faith, worship and morals. Each of the main themes has some subthemes that illustrate the practice or characteristics that form the hablumminallah by the informant.

Faith has three subthemes, namely the belief in the blessing of sustenance, the provision of Allah's provision and the strength of prayer. The informant explains that the practices of alms and zakat that are practiced will increase the blessings of earned income. This encourages them to continue to succeed.

... I do not forget to issue zakat and alms as both give a lot of blessings to sustenance.

Informants also believe that sustenance is the provision of Allah in which human beings work, while the result is the provision of Allah. This is explained by the R4 informant on how she enters the tender auction of jewellery.

Getting the tender for gold auction depends on sustenance. If there is susntenance, you will get it. If you have lots of sustenance, then you will get more. (R4) 
In addition, informants also believe in the power of prayer as a Muslim weapon in life. It is clear that informant R2 stated that she not only prayed much but also seek for prayers from her friends and relatives so she continued to succeed in business.

.. Yes, we have to pray a lot. Even I, myself really hope for prayers from friends and people around so that I can achieve what I want. (R2)

In order to create and maintain hablumminallah, entrepreneurs take care of the aspect of their faith by instilling Allah's conviction. The right faith in Allah is the milestone of ultimate success in business and any work. Believing there is a blessing on sustenance, the strength of prayer in business dealings and believing that sustenance is determined by Allah can make an entrepreneur strong, persistent, not easy to give up. This is because such entrepreneurs believe that if they fail, it means that the sustenance is not for them. They will keep on trying to get the sustenance that has been set by Allah. They even love to give alms and zakat to increase the blessing that been acquired. The finding of this research is supported by past research as taqwa is attained by having a good relationship between man and Allah. To have a good relationship with Allah, entrepreneurs should have pure faith (Ghozali \& Kamri, 2015), as well as taqwa (Rameli, Aziz \& Wahab, 2013; Azmi \& Yaacob, 2012).

Worship also refers to the compulsory dictatorship and practice of Islam. It encompasses the sincere and proper intention of doing business, completing the obligations of prayers and zakat. Informant also implements waqf, alms, dhuha prayer and reciting al-Quran and praying. All these practices reflect the relationship with Allah (hablumminallah).

For example, the informant stated that intent is very important because it determines the blessings of sustenance. This is stated by informant R2 dan R4. In carrying out business, R2 informant intend to help people.

Our intention need to be right as it gives blessings. (R4)

From the beginning I intend to help the villagers.. (R2)

In addition, the study also found that entrepreneurs have the intention to give charity when doing business. This is proved by an interview with R4 informant. She stated as follows:

This shop is based on the concept of charity while selling. Wages are not expensive because the intention since the opening of this jewellery shop is to help the Malays...(R4)

The results of the interview analysis found that Muslim women entrepreneurs were very concerned about their business zakat payments. This is as shown by the informants R2, R3 and R4 when they use their own way of distributing zakat to the needy without going through the zakat office. For example the R4 informant explains as follows: 
INTERNATIONAL JOURNAL OF ACADEMIC RESEARCH IN BUSINESS AND SOCIAL SCIENCES

Vol. 8, No. 5, May 2018, E-ISSN: 2222-6990 ㄷ 2018 HRMARS

If the worker is sick, I will give them help or zakat. If they are eligible for zakat, I will give them business zakat. (R4)

Other than business zakat, informants are also found to give alms and endowment. This is as stated by $\mathrm{R} 2$ informant below.

Yes, endowment. Normally every month there will be people that came to ask for donation (endowment) for the building of surau and so on. I do gave it to them. As example, yesterday there are people came to ask for donation for building a mosque... (R2)

The result of interview also found out that informant do know the benefits and practices dhuha prayer which suggested by the Prophet. Among the main benefits is as the opening of sustenance. This is shared by R1 and R4 as followed.

Alhamdulillah the dhuha prayers I always practice, It's just not every day.. (R1)

Dhuha prayer is performed, recitement of surah al-Waqi'ah, Yasin on Television (business premises).. (R4)

Among the advantages of reading al-Quran is to gain peace of mind for its readers and also to receive blessings in life. Al-Quran is not just a guide and guidance for people in the world, but can intercede in the hereafter. This practice should not be isolated in the life dictionary of Muslim entrepreneurs, even among the major practices. This is clearly proved by informants R2 and R4 interviewed. They are very concerned about the reading of the verses of the Al-Quran and believe in their superiority. For example R2 explained:

I love to recite Yasin either after circumcision or compulsory prayers. (R2)

Successful Muslim women entrepreneurs maintain their relationship with Allah (hablumminallah) through the practice of worship performed. The result of this research is according with Azmi (2014) which found out that Muslim women entrepreneurs at Siti Khadijah Market, Kota Bharu also practice the individual or fardu ain obligations such as covering aurat, reading the Quran, tahajjud and prayer. The entrepreneurs are also reported to issue zakat and give alms as their worship practices. All of these practices form a close relationship in the context of the slave with the creator which is Allah.

Moral refers to the subtheme of gratitude, tawakal, patience, and generosity. Gratitude is the recognition of the grace that Allah has bestowed and accompanied by submission to it and uses it in accordance with the rules and will of Allah SWT. As a Muslim, successful female Muslim entrepreneurs also have gratitude in carrying out their business activities. This is as shared by informers R2 and R4 when it is clear to show gratitude when it comes to favors and help.

I feel so grateful. (R2)

Alhamdulillah, I get help and support from my uncle.(R4) 
Informants also put their trust in Allah. Tawakal is a feeling of resignation to Allah SWT against His provision accompanied by all the power and effort to obey, and fulfill all His commandments. With the nature of tawakal, Muslim women entrepreneurs are always grateful for all their efforts in something successful. On the contrary she will be submissive and sincere to accept if her business fails. Muslim women entrepreneurs are found to be tawakal when they hope and submit to Allah SWT in their sustenance. They also tawakal on whatever they want and achieve. This is as demonstrated by R4 informant.

Everything depends on the situation, if Allah permits then can earn more ... (R4)

Informants too did practice patience. Patience according to Islam means refraining from various hardships and difficulties. The patience becomes strengths which leads informants to be successful. This thing was explained by R2 informant when she believes that entrepreneurs should have lots of patience in facing challenges in business. On the other hand, R3 informants stated that with patience, she was increasingly persevering in the wake of her fall in business.

.. But it is okay, Allah showed me the way to solve problems. The hardships and tests that Allah gives are just temporary. Therefore, we have to be patience. (R2)

With the familiar experience of falling, calls from the bank, cars are pulled.. All of them made me tough. (R3)

The patience can also be seen when R3 informant are persistent in business. One of them was facing the bank, failure to pay debt within the time given, cars were pulled by bank when unable to pay bank loan and so on.

From the result of interview analysis, it came out that informants do have the generosity. Generous in this context of discussion means the person who loves to give, or is very kind in giving. R2 informant is not too strict in determining the price of her products, even can be negotiable.

Usually the price can be negotiable. I will count less and apply the nearest price. For example, the price is RM3645 and I will deduct it to RM3400 only. (R2)

Similarly, informants are generous in scales by giving more weight to buyers as did R4 informant.

In scales I will take heavier scales. It is fine to give more weight to the customer. (R4)

The appreciation of moral values by informants in the context of entrepreneurship is important for the survival of human relationships with its Creator. Gratitude, tawakkal, patience and generosity are commendable and make one closer to Allah. The findings of this study coincide with the findings of Ghozali and Kamri (2015), who find that good morality is one of the characteristics of Islamic personality that has a positive effect on the quality of work. Rameli, Aziz and Wahab (2013) stated that high moral values are one of the characteristics of a successful 
Muslim entrepreneur. Good morality and high moral values here can be understood as a noble character in this study. This finding is also in line with Abdullah (2013) who finds to hold firmly in Islamic way of life and appreciation of noble values as one of the two criteria of successful Muslim entrepreneurs. The way of life of Islam and the appreciation of the pure values embodied in it the themes of faith, worship and morality form a good relationship between man and Allah (hablumminallah). The finding of theme and subtheme could be illustrated in Diagrame 1 (Bakar \& Yusof, 2017).

\section{Conclusion}

This research shows that Islamic faith, worship and morality could develop and establish a good relationship between man and Allah. A good hablumminallah could be acheived by having a truth faith to Allah including confidence in prayer, the concept of sustenance and blessings. At the same time, the practice of worship including general worship and special worship such as sincere intentions, zakat, waqf, alms, sunat prayer, reading al-Quran and praying are very important in achieving a good relationship with Allah. Besides, good morals such as gratitude, tawakal, patience and generous should be applied by Muslim woman entreprenuer as it strenghten the relationship with Allah and contribute to entreprenuer success. In the context of entrepreneur, a good relationship with Allah will result in obeying Allah's command pertaining to entrepreneurial activities. As such, Muslim women entrepreneur should apply Islamic teaching in entrepreneur activities including production, human resource, finance and so forth. While this paper is limited to the discussion on hablumminallah among Muslim women entrepreneur, it is suggested for future research to investigate the practice of habluminannas among Muslim entrepreneur. Future research should explore how Muslim entrepreneur develop their hablumminannas within their networking such as their worker, customer and supplier. 
INTERNATIONAL JOURNAL OF ACADEMIC RESEARCH IN BUSINESS AND SOCIAL SCIENCES

Diagrame 1: The finding of theme and subtheme for successful Muslim women entreprenuer

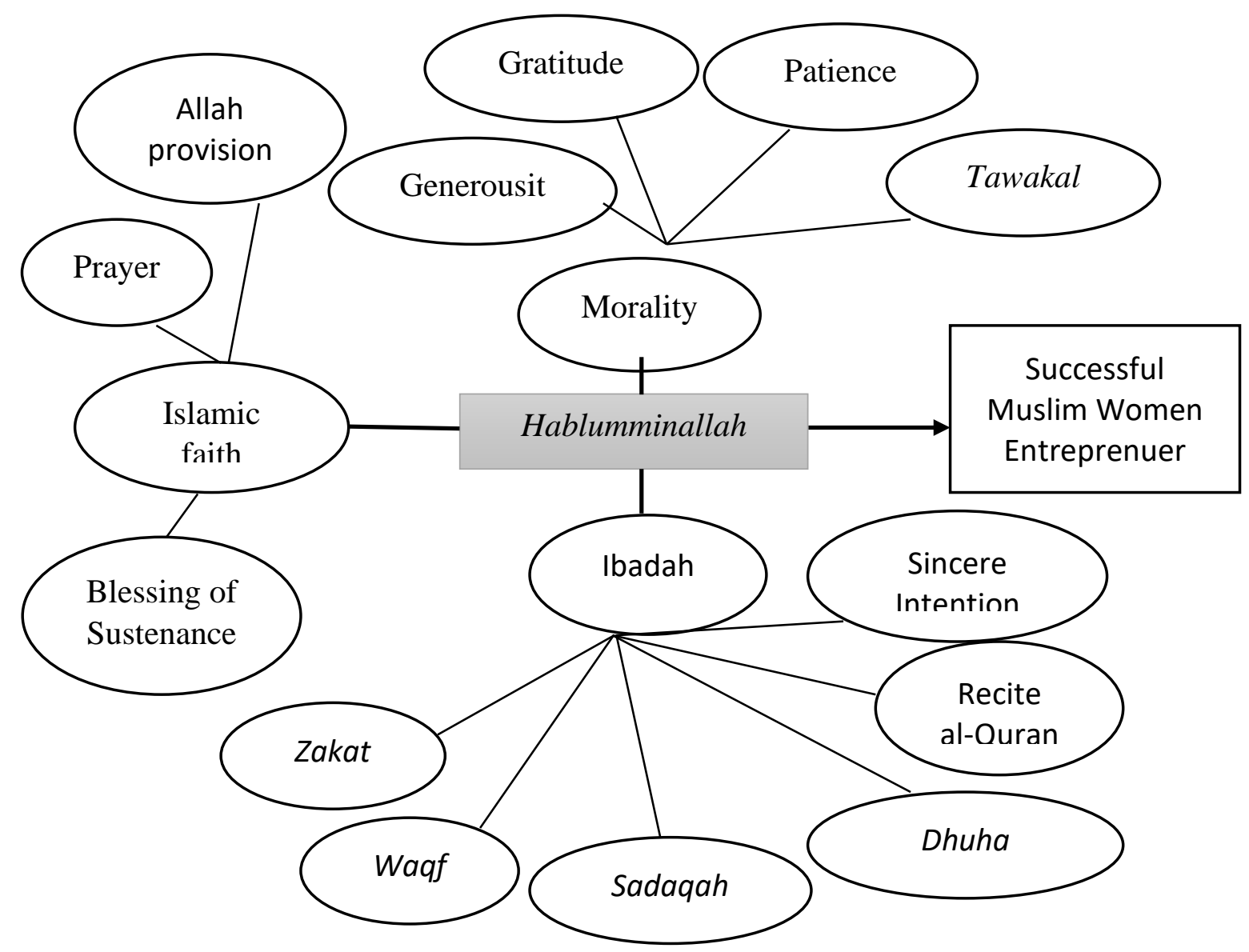

\section{Acknowledgement}

This paper is a part of research at Islamic Business School, University Utara Malaysia and financially supported by University Utara Malaysia.

\section{Corresponding Author}

Syarifah Md Yusof

Pusat Pengajian Perniagaan Islam (IBS)

Universiti Utara Malaysia

06000 Sintok Kedah

Malaysia

Email: syarifah@uum.edu.my

\section{References}

Abdullah, S. (2013). Pure values among entrepreneurs: A study on successful entrepreneurs of Perlis MARA. International Journal of Business and Social Science, 4(3), 171-177. 
Al-Ghazali. (1990). Al-Imam Hujjah al-Islam Abi Hamid. Ihya' 'Ulum al-Din, juzu' 3. Damsyik: Dar al-Khayr.

Al-Qaradawi, Y. (1973). Fiqh al-Zakah. Beirut: Mu'assasah al-Risalah.

Al-Qaradawi, Y. (2010). Fiqh Ekonomi Islam. (Arshad, M. D., Penterjemah), Kuala Lumpur: Blue-T Publication Sdn Bhd.

Azmi, I. A. G., \& Yaacob, Y. (2012). Entrepreneur's Personality From Islamic Perspective; A Study of Succesful Muslim Entrepreneurs in Malaysia. Kertas Kerja dibentangkan di International Conference On Economic Business Research. Phnom Pen pada Disember 2012.

Azmi, I. A. G. (2014). The implementation of islamic business practices of women traders: A study in an Islamic state in a developing country. Global Journal Al-Thaqafah, 4(2), 17-28.

Din, H. (2015). Manusia dan Islam. Kuala Lumpur: Dewan Bahasa dan Pustaka.

Ghozali, M., \& Kamri, N. A. (2015). Islamic personality and professionalism at work: A theoretical analysis. Jurnal Syariah, 23(2), 255-286.

Hamed, A. B., \& Yusof, S. M. (2008). Jaringan usahawan holistik: Strategi usahawan menuju alfalah. Kertas kerja dibentangkan di Seminar Keusahawanan Islam II Peringkat Kebangsaan 2008, Akademi Pengajian Islam, Universiti Malaya pada 15 Oktober 2008.

Kamil, N. M., Al-Kahtani, A. H., \& Sulaiman, M. (2011). The components of spirituality in the business organizational context: The case of Malaysia. Asian Journal of Business and Management Sciences, 1(2), 166-180.

Kamus Dewan Online, http://prpm.dbp.gov.my/cari1?keyword=kamus\%20online.

Kedah, Z., \& Adamu, I. M. (2011). Spirituality in entrepreneurship from Islamic perspective. Dalam Osman, A. A. M. \& Suhaimi, M. S. (Ed.), Spirituality in Management From Islamic Perspective. Selangor: IIUM Press.

Kuratko, D. F., \& Hodgetts, R. M. (2007). Entrepreneurship: Theory, process, practice (Edisi Ketujuh). Mason, $\mathrm{OH}$ : Thomson South-Western.

Miles, M. B., Huberman, A. M., \& Saldana, J. (2014). Qualitative data analysis: A method sourcebook (Edisi Ketiga). United States: Sage Publication, Inc.

Mohsen, N. R. M. (2007). Leadership from the Quran, operationalization of concepts and empirical analysis: Relationship between taqwa, trust and business leadership effectiveness. (Tesis doktor falsafah tidak diterbitkan). Universiti Sains Malaysia, Malaysia.

Mubarak, M. Z., Rahman, A. A., \& Yaacob, M. R. (2015). Elemen kerohanian dalam keusahawanan Islam: kajian terhadap usahawan berjaya di negeri Kelantan. Journal of Business and Social Development, 3(1), 43-53.

Rameli, M. F. P., Aziz, M. R. A., \& Wahab, K. A. (2013). The muslim entrepreneurs characteristic from mu'amalat perspective. Kertas kerja diterbitkan di The 5th Islamic Economic System Conference 2013 (iECONS2013), Kuala Lumpur: Universiti Sains Islam Malaysia (USIM) pada 4-5 September 2013.

Rameli, M. F. P., Aziz, M. R. A., Wahab, K. A., \& Amin, S. M. (2014). Etika perniagaan Islam: Pengalaman usahawan Muslim di Melaka. Prosiding PERKEM ke-9, 442 - 450.

Samsudin, Y. N. H., \& Kamri, N. A.. (2008). Pembangunan usahawan muslim berteraskan paradigma tauhid: Satu pendekatan. Kertas kerja dibentangkan dalam Seminar Keusahawanan Islam II Peringkat Kebangsaan.

Yusof, S. M., Hameed, A. B., \& Tahir, R. M. (2017). Gaya Hidup Halal dalam kalangan usahawan wanita Muslim berjaya. Dalam Ahmad, F. A., Ismail, N. S. \& Samsudin, N. H. (Ed.), Proceeding 
INTERNATIONAL JOURNAL OF ACADEMIC RESEARCH IN BUSINESS AND SOCIAL SCIENCES

Vol. 8, No. 5, May 2018, E-ISSN: 2222-6990 @ 2018 HRMARS

of International Islamic Development Management Conference (IDMAC 2017). (89-100).

Pulau Pinang: Centre for Islamic Development Management Studies (ISDEV). 